\title{
Faktor risiko gizi buruk pada balita di Kabupaten Donggala Provinsi Sulawesi Tengah
}

\author{
Risk factors of severe malnutrition in children underfive in Donggala Central Sulawesi Province
}

\author{
Eka Prasetia Hati Baculu1, M.Juffrie², Siti Helmyati ${ }^{3}$
}

\begin{abstract}
Background: Severe malnutrition is a state of severe malnourished condition caused by low consumption of energy and protein in a long time. Severe malnutrition interferes the children growth and development, moreover malnourished children are vulnerable to get infectious diseases, even the death.

Objectives: To analyze the risk factors of severe malnutrition among children under five in Donggala, Central of Sulawesi Province.

Methods: This study used case-control (observational study). The study was conducted in District Dampelas Donggala on July to September 2014. The population was all children underfive selected by total sampling method. The samples were 64 children aged 0-59 months which separated into 2 groups, case and control group. The independent variables were the level of energy intake of protein, parenting, and infectious diseases, while the dependent variable was the incidence of severe malnutrition among children under five. Data were obtained by direct interview using questionnaire and recall 24 hours to determine the level of energy and protein intake. The data collected were analyzed using univariate analysis (descriptive), bivariate (chi-square), and multivariate (multiple logistic regression).

Results: The result of this study based on the bivariate analysis presented that the level of energy intake $(O R=9.86,95 \% \mathrm{Cl}: 3.49-27.89)$, infectious disease (OR=2.83, 95\% Cl:1.10-7.31), and as low birth weight external variables (OR=5.76, 95\% Cl:1.43-23.20) significantly associated with the incidence of severe malnutrition. There were no significant association between the level of protein intake (OR=1.18, 95\% $\mathrm{Cl}: 0.47-2.92)$ and parenting (OR=1.21, 95\% Cl:0.50-2.92) with the incidence of severe malnutrition. In the other hand, based on multivariate analysis by controlling the variable of low birth weight history, this study's result presented that the level of energy intake had the strongest association with the risk of incidence of severe malnutrition compared to the other variables.
\end{abstract}

Conclusions: The level of energy intake and infectious disease were the risk factors for the incidence of severe malnutrition among children under five, while the level of protein intake and parenting were not.

KEYWORDS: children underfive, energy, infectious disease, parenting, protein, severe malnutrition

\begin{abstract}
ABSTRAK
Latar belakang: Gizi buruk adalah keadaan kurang gizi tingkat berat yang disebabkan oleh rendahnya konsumsi energi dan protein dalam waktu cukup lama. Kekurangan gizi selain mengganggu pertumbuhan dan perkembangan, dapat pula mengakibatkan balita rentan terhadap penyakit infeksi bahkan dapat menyebabkan kematian.

Tujuan: Untuk menganalisis faktor risiko kejadian gizi buruk pada balita di Kabupaten Donggala, Provinsi Sulawesi Tengah.

Metode: Jenis penelitian ini observasional dengan rancangan case-control. Penelitian dilakukan di Kecamatan Dampelas, Kabupaten Donggala pada bulan Juli sampai September 2014. Populasi adalah semua balita dan sampel ditentukan dengan metode total sampling. Balita usia 0-59 bulan yang berjumlah
\end{abstract}

\footnotetext{
${ }^{1}$ Bagian Program Pasca Sarjana, Program Studi IImu Kesehatan Masyarakat, Fakultas Kedokteran UGM,

Jl.Farmako Sekip Utara, Yogyakarta, e-mail: ekaprasetiahati@gmail.com

2 Bagian Instalasi Kesehatan Anak RSUP Dr.Sarjito, JI.Kesehatan, Yogyakarta

${ }^{3}$ Bagian Program Studi Gizi dan Kesehatan, Fakultas Kedokteran UGM, Jl. Farmako Sekip Utara, Yogyakarta
} 
64 dimasukkan pada masing-masing kelompok kasus dan kontrol. Variabel bebas yaitu tingkat asupan energi protein, pola asuh, dan penyakit infeksi sedangkan variabel terikatnya adalah kejadian gizi buruk pada balita. Data diperoleh dengan wawancara langsung menggunakan kuesioner dan recall 24 jam untuk mengetahui tingkat asupan energi dan protein. Data dianalisis dengan analisis univariat (deskriptif), bivariat (chi-square), dan multivariat (regresi logistik berganda).

Hasil: Hasil analisis bivariat menunjukkan bahwa tingkat asupan energi (OR=9,86, 95\% Cl:3,49-27,89), penyakit infeksi $(O R=2,83,95 \% \mathrm{Cl}: 1,10-7,31)$, dan variabel luar $B B L R(O R=5,76,95 \% \mathrm{Cl}: 1,43-23,20)$ berhubungan signifikan dengan gizi buruk. Tidak ada hubungan yang signifikan antara tingkat asupan protein $(O R=1,18,95 \% \mathrm{Cl}: 0,47-2,92)$ dan pola asuh $(\mathrm{OR}=1,21,95 \% \mathrm{Cl}: 0,50-2,92)$ dengan gizi buruk. Hasil analisis multivariat dengan mengendalikan riwayat BBLR menunjukkan bahwa tingkat asupan energi memiliki hubungan kuat dengan risiko kejadian gizi buruk dibandingkan variabel lainnya.

Kesimpulan: Tingkat asupan energi dan penyakit infeksi merupakan faktor risiko kejadian gizi buruk pada balita, sedangkan tingkat asupan protein dan pola asuh bukan merupakan faktor risiko.

KATA KUNCI: balita, energi, penyakit infeksi, pola asuh, protein, gizi buruk, gizi

\section{PENDAHULUAN}

Masalah gizi merupakan gangguan pada beberapa segi kesejahteraan perorangan dan atau masyarakat yang disebabkan oleh tidak terpenuhinya kebutuhan akan zat gizi dari makanan. Bayi dan anak-anak adalah kelompok masyarakat yang paling rentan terhadap masalah gizi karena memerlukan nutrisi tambahan untuk pertumbuhan dan perkembangan, memiliki cadangan energi yang terbatas, dan masih tergantung pada orang lain (1).

Banyak faktor yang mempengaruhi terjadinya gizi buruk pada balita dan beberapa penyebab langsungnya adalah kurangnya asupan makanan dan adanya penyakit infeksi. Penyebab tersebut selalu diiringi dengan latar belakang lain yang lebih kompleks seperti kondisi sosial ekonomi, tingkat pendidikan, kondisi lingkungan dan pola asuh yang diberikan kepada balita (2). Berdasarkan data riset kesehatan dasar (Riskesdas) tahun 2013, prevalensi gizi buruk di Indonesia sebesar 5,7\% dan Sulawesi Tengah sebesar $6,6 \%$ (3). Senada dengan data ini, berdasarkan Laporan Tahunan Dinas Kesehatan Kabupaten Donggala tahun 2013 diperoleh data sebesar 14,6\% balita di Kabupaten Donggala mengalami gizi buruk (4). Berdasarkan data tersebut, dapat diketahui prevalensi gizi buruk di Kabupaten Donggala berada di atas prevalensi nasional begitu pula dengan prevalensi gizi buruk di Sulawesi Tengah juga mengalami peningkatan secara nasional dan hal ini masih menjadi masalah di beberapa kabupaten di Sulawesi Tengah salah satunya Kabupaten Donggala.

Kecamatan Dampelas merupakan salah satu kecamatan di Kabupaten Donggala, sebelah utara berbatasan dengan Kecamatan Sojol, sebelah barat berbatasan dengan Selat Makassar, sebelah timur dengan Kabupaten Parigi Moutong dan sebelah selatan berbatasan dengan Kecamatan Balaesang. Kondisi ini menjadikan Kecamatan Dampelas menjadi daerah yang dilalui jalan antarkota dan kabupaten serta merupakan jalan trans antar Sulawesi. Sementara itu, prevalensi balita gizi buruk di Kecamatan Dampelas sebesar 14,2\%, merupakan tertinggi kedua setelah Kecamatan Sojol di Kabupaten Donggala (4).

Tingginya angka gizi buruk pada balita apabila tidak segera diatasi, maka akan memberikan dampak baik pada individu, keluarga hingga dampak bagi masyarakat. Tujuan dari penelitian ini untuk menganalisis faktor risiko kejadian gizi buruk pada balita di Kabupaten Donggala, Provinsi Sulawesi Tengah. Penelitian ini telah mendapat surat kelayakan etik dari Komisi Etik Fakultas Kedoteran Universitas Gadjah Mada dengan nomor Ref: KE/FK/ 716/ EC.

\section{BAHAN DAN METODE}

Jenis penelitian ini adalah observasional dengan rancangan case-control. Studi ini membandingkan 64 balita yang memiliki status gizi buruk dengan z-skor BB/U <-3 SD untuk kelompok kasus dan 64 balita yang memiliki status gizi baik 
dengan z-skor BB/U -2 s/d 2 SD. Penelitian ini dilaksanakan di Kecamatan Dampelas, Kabupaten Donggala Provinsi Sulawesi Tengah. Pemilihan lokasi dengan cara purposive dengan melihat jumlah balita gizi buruk tertinggi ke dua di Kabupaten Donggala tahun 2013. Kontrol dipilih dari satu populasi dengan kasus dan dilakukan matching jenis kelamin dan rasio 1:1.

Variabel terikat adalah kejadian gizi buruk pada balita, sedangkan variabel bebas adalah tingkat asupan energi, tingkat asupan protein, riwayat penyakit infeksi, dan pola asuh. Variabel luar adalah pendidikan ayah, pendidikan ibu, pengetahuan gizi ibu, pendapatan keluarga, jumlah anggota keluarga, riwayat berat bayi lahir rendah (BBLR) dan ASI eksklusif. Instrumen yang digunakan untuk mengukur variabel penelitian yaitu: kuesioner terstruktur untuk wawancara, instrumen berat badan balita menggunakan dacin yang telah dikalibrasi sebelumnya, recall 24 jam yang digunakan untuk mengukur tingkat asupan energi dan protein.

Analisis data dilakukan dengan analisis univariat, analisis bivariat menggunakan chi-square dengan interval kepercayaan $(95 \% \mathrm{Cl})$ dan tingkat kemaknaan $p<0,05$. Analisis multivariat dilakukan dengan uji regresi logistik berganda dan analisis stratifikasi dilakukan dengan uji Mantel-Haenzel.

\section{HASIL}

Penelitian ini melibatkan 128 balita dan ibunya. Berikut gambaran karakteristik subjek penelitian pada masing-masing variabel dengan melihat distribusi frekuensi (Tabel 1).

Berdasarkan Tabel 1, menunjukkan bahwa riwayat $B B L R$, berbeda secara signifikan antara kelompok kasus dan kontrol $(p<0,05)$. Sementara karakteristik subjek penelitian lain tidak ada perbedaan yang bermakna $(p>0,05)$. Hal ini

Tabel 1. Distribusi frekuensi karakteristik subjek penelitian berdasarkan sosial ekonomi dan status gizi balita

\begin{tabular}{|c|c|c|c|c|c|}
\hline \multirow{2}{*}{ Variabel } & \multicolumn{2}{|c|}{ Kasus ( $n=64)$} & \multicolumn{2}{|c|}{ Kontrol (n=64) } & \multirow{2}{*}{$\mathbf{p}$} \\
\hline & $\mathbf{n}$ & $\%$ & $\mathbf{n}$ & $\%$ & \\
\hline \multicolumn{6}{|l|}{ Jenis kelamin } \\
\hline Laki-laki & 26 & 40,63 & 26 & 40,63 & 1,00 \\
\hline Perempuan & 38 & 59,38 & 38 & 59,38 & \\
\hline \multicolumn{6}{|l|}{ Berat badan lahir } \\
\hline BBLR & 17 & 26,56 & 4 & 6,25 & $0,002^{*}$ \\
\hline Normal & 47 & 73,44 & 60 & 93,75 & \\
\hline \multicolumn{6}{|l|}{ ASI eksklusif } \\
\hline Tidak ASI eksklusif & 49 & 76,56 & 44 & 68,75 & 0,32 \\
\hline ASI eksklusif & 15 & 23,44 & 20 & 31,25 & \\
\hline \multicolumn{6}{|l|}{ Pendidikan ayah } \\
\hline Rendah (tidak sekolah, tidak tamat SD/SMP, tamat SD/SMP) & 49 & 76,56 & 54 & 84,38 & 0,27 \\
\hline Tinggi (tamat SMA, tamat Diploma/perguruan tinggi) & 15 & 23,44 & 10 & 15,63 & \\
\hline \multicolumn{6}{|l|}{ Pendidikan ibu } \\
\hline Rendah (tidak sekolah, tidak tamat SD/SMP, tamat SD/SMP) & 54 & 84,38 & 54 & 84,38 & 1,00 \\
\hline Tinggi (tamat SMA, tamat Diploma/perguruan tinggi) & 10 & 15,63 & 10 & 15,63 & \\
\hline \multicolumn{6}{|l|}{ Jumlah anggota keluarga } \\
\hline Sedikit ( $\leq 4$ orang) & 22 & 34,38 & 22 & 34,38 & 1,00 \\
\hline Banyak (>4 orang) & 42 & 65,63 & 42 & 65,63 & \\
\hline \multicolumn{6}{|l|}{ Pengetahuan gizi } \\
\hline Kurang (jawaban benar $<77$ ) & 38 & 59,38 & 28 & 43,75 & 0,07 \\
\hline Baik (jawaban benar $\geq 77$ ) & 26 & 40,63 & 36 & 56,25 & \\
\hline \multicolumn{6}{|l|}{ Pendapatan keluarga } \\
\hline Rendah (< Rp 995.000/bln) & 48 & 75,00 & 46 & 71,88 & 0,69 \\
\hline Tinggi ( $\geq \operatorname{Rp} 995.000 / \mathrm{bln})$ & 16 & 25,00 & 18 & 28,13 & \\
\hline \multicolumn{6}{|l|}{ Pola asuh } \\
\hline Kurang (skor <70) & 32 & 50,00 & 22 & 34,38 & 0,07 \\
\hline Baik (skor $\geq 70$ ) & 32 & 50,00 & 42 & 65,63 & \\
\hline
\end{tabular}

* Signifikan $(p<0,05)$ 
menunjukkan bahwa antara kelompok kasus dan kelompok kontrol memiliki distribusi yang setara dalam karakteristik tersebut.

Berdasarkan Gambar 1, terlihat rata-rata \% AKG tingkat asupan energi balita gizi buruk lebih rendah $10,34 \%$ dibanding dengan balita gizi normal. Rata-rata \% AKG tingkat asupan protein juga terlihat bahwa tingkat asupan protein balita gizi buruk lebih rendah $21,51 \%$ dibandingkan dengan tingkat asupan protein pada balita gizi normal.

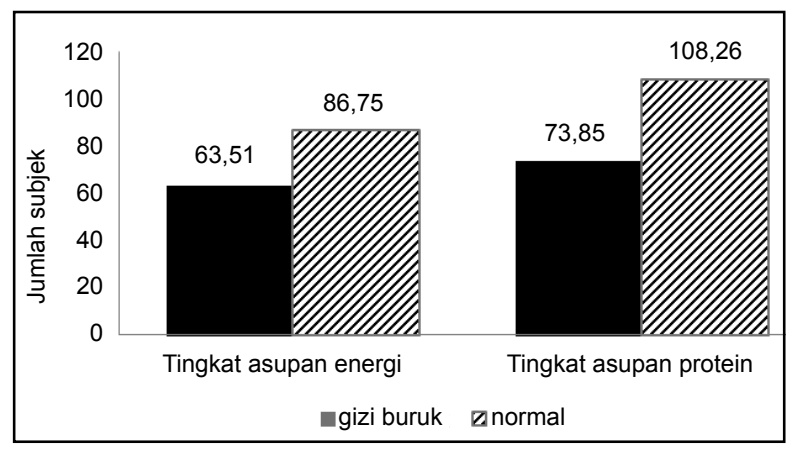

Gambar 1. Rata-rata asupan energi dan protein sehari

Terdapat hubungan yang signifikan antara tingkat asupan energi dan riwayat penyakit infeksi dengan kejadian gizi buruk $(p<0,05)$, sedangkan tingkat asupan protein dan pola asuh tidak menunjukkan hubungan yang signifikan dengan kejadian gizi buruk $(p>0,05)$ (Tabel 2 ).
Tidak ada hubungan yang signifikan antara pendidikan ibu, pendidikan ayah, pengetahuan gizi, jumlah anggota keluarga, ASI eksklusif, dan pendapatan keluarga dengan kejadian gizi buruk $(p>0,05)$. Namun demikian, terlihat adanya hubungan yang signifikan antara BBLR dengan kejadian gizi buruk dengan nilai OR sebesar 5,43 $(p<0,05)$. Hal ini berarti anak yang memiliki berat badan lahir rendah memiliki risiko 5,43 kali lebih besar untuk terkena gizi buruk dibandingkan dengan anak yang memiliki berat badan lahir normal (Tabel 3).

Pada penelitian ini, analisis multivariat yang digunakan adalah regresi logistik. Pada analisis ini dilakukan dengan menguji hubungan antara variabel bebas dengan variabel terikat setelah mengontrol variabel luar yang memiliki nilai $p<0,25$ pada analisis bivariat. Variabel yang memiliki nilai $p<0,25$ yaitu tingkat asupan energi, tingkat asupan protein, penyakit infeksi, pola asuh, berat badan lahir rendah, pendidikan ayah, dan pengetahuan gizi. Beberapa model analisis regresi logistik yang telah dilakukan dapat dilihat pada Tabel 4.

Berdasarkan Tabel 4, model yang dipilih adalah model 5 . Model 5 dipilih cukup baik untuk menjelaskan hubungan tingkat asupan energi, tingkat asupan protein, riwayat penyakit infeksi dan pola asuh dengan kejadian gizi buruk karena model 5 telah mempertimbangkan semua variabel yang

Tabel 2. Analisis bivariat variabel bebas terhadap kejadian gizi buruk

\begin{tabular}{|c|c|c|c|c|c|c|}
\hline \multirow{3}{*}{ Variabel } & \multicolumn{4}{|c|}{ Status gizi } & \multirow{3}{*}{$\mathbf{p}$} & \multirow{3}{*}{$\begin{array}{c}\text { OR } \\
(95 \% \mathrm{Cl})\end{array}$} \\
\hline & \multicolumn{2}{|c|}{ Gizi buruk } & \multicolumn{2}{|c|}{ Normal } & & \\
\hline & $\mathbf{n}$ & $\%$ & $\mathbf{n}$ & $\%$ & & \\
\hline \multicolumn{7}{|l|}{ Tingkat asupan energi } \\
\hline Kurang (asupan <70 \% AKG) & 50 & 78,15 & 27 & 42,19 & \multirow{2}{*}{$0,00^{*}$} & 4,89 \\
\hline Cukup (asupan $\geq 70 \%$ AKG) & 14 & 21,88 & 37 & 57,81 & & $(2,12-11,49)$ \\
\hline \multicolumn{7}{|l|}{ Tingkat asupan protein } \\
\hline Kurang (asupan <80 \% AKG) & 26 & 40,63 & 17 & 26,56 & \multirow{2}{*}{0,09} & \\
\hline Cukup (asupan $\geq 80 \%$ AKG) & 38 & 59,38 & 47 & 73,44 & & $(0,84-4,29)$ \\
\hline \multicolumn{7}{|l|}{ Riwayat penyakit infeksi } \\
\hline Ada infeksi & 41 & 64,06 & 29 & 45,31 & \multirow{2}{*}{$0,03^{*}$} & 2,15 \\
\hline Tidak ada infeksi & 23 & 35,94 & 35 & 54,69 & & $(1,06-4,37)$ \\
\hline \multicolumn{7}{|l|}{ Pola asuh } \\
\hline Kurang (skor <70) & 32 & 50,00 & 22 & 34,38 & \multirow{2}{*}{0,07} & 1,91 \\
\hline Baik (skor $\geq 70$ ) & 32 & 50,00 & 42 & 65,63 & & $(0,88-4,14)$ \\
\hline
\end{tabular}

*) Signifikan $(p<0,05)$ 
Tabel 3. Analisis bivariabel variabel luar terhadap kejadian gizi buruk

\begin{tabular}{|c|c|c|c|c|c|c|}
\hline \multirow{3}{*}{ Variabel } & \multicolumn{4}{|c|}{ Status gizi } & \multirow{3}{*}{$\mathbf{p}$} & \multirow{3}{*}{$\begin{array}{c}\text { OR } \\
(95 \% \mathrm{Cl})\end{array}$} \\
\hline & \multicolumn{2}{|c|}{ Gizi buruk } & \multicolumn{2}{|c|}{ Normal } & & \\
\hline & $\mathbf{n}$ & $\%$ & $\mathbf{n}$ & $\%$ & & \\
\hline \multicolumn{7}{|l|}{ Pendidikan ibu } \\
\hline Rendah (tidak sekolah, tidak tamat SD/SMP, tamat SD/SMP) & 54 & 84,38 & 54 & 84,38 & \multirow{2}{*}{1,00} & 1 \\
\hline Tinggi (tamat SMA, tamat Diploma/perguruan tinggi) & 10 & 15,63 & 10 & 15,63 & & $(0,34-2,92)$ \\
\hline \multicolumn{7}{|l|}{ Pendidikan ayah } \\
\hline Rendah (tidak sekolah, tidak tamat SD/SMP, tamat SD/SMP) & 49 & 76,56 & 54 & 84,38 & \multirow{2}{*}{0,27} & 0,60 \\
\hline Tinggi (tamat SMA, tamat Diploma/perguruan tinggi) & 15 & 23,44 & 10 & 15,63 & & $(0,22-1,60)$ \\
\hline \multicolumn{7}{|l|}{ Pengetahuan gizi } \\
\hline Kurang (jawaban benar <77) & 38 & 59,38 & 28 & 43,75 & \multirow{2}{*}{0,07} & 1,88 \\
\hline Baik (jawaban benar $\geq 77$ ) & 26 & 40,63 & 51 & 56,25 & & $(0,88-4,03)$ \\
\hline \multicolumn{7}{|l|}{ Jumlah anggota keluarga } \\
\hline Sedikit $(\leq 4$ orang) & 22 & 34,38 & 22 & 34,38 & \multirow{2}{*}{1,00} & 1 \\
\hline Banyak (> 4 orang) & 42 & 65,63 & 42 & 65,63 & & $(0,45-2,21)$ \\
\hline \multicolumn{7}{|l|}{ Berat badan lahir } \\
\hline $\operatorname{BBLR}(<2.500 \mathrm{~g})$ & 17 & 26,56 & 4 & 6,25 & \multirow{2}{*}{$0,002^{*}$} & 5,43 \\
\hline Normal $(\geq 2,500 \mathrm{~g})$ & 47 & 73,44 & 60 & 93,75 & & $(1,60-3,36)$ \\
\hline \multicolumn{7}{|l|}{ ASI eksklusif } \\
\hline Tidak ASI eksklusif & 49 & 76,56 & 44 & 68,75 & \multirow{2}{*}{0,32} & 1,48 \\
\hline ASI eksklusif & 15 & 23,44 & 20 & 31,25 & & $(0,63-3,52)$ \\
\hline \multicolumn{7}{|l|}{ Pendapatan keluarga } \\
\hline Rendah (< Rp 995.000/bln) & 48 & 75,00 & 46 & 71,88 & \multirow{2}{*}{0,69} & 1,17 \\
\hline Tinggi ( $\geq$ Rp 995.000/bln) & 16 & 25,00 & 18 & 28,13 & & $(0,50-2,78)$ \\
\hline
\end{tabular}

*Signifikan $(p<0,05)$

Tabel 4. Tabel analisis regresi logistik

\begin{tabular}{|c|c|c|c|c|c|}
\hline Variabel & $\begin{array}{c}\text { Model } 1 \\
\text { OR } \\
(95 \% \mathrm{Cl})\end{array}$ & $\begin{array}{c}\text { Model } 2 \\
\text { OR } \\
(95 \% \mathrm{Cl})\end{array}$ & $\begin{array}{c}\text { Model } 3 \\
\text { OR } \\
(95 \% \mathrm{Cl})\end{array}$ & $\begin{array}{c}\text { Model } 4 \\
\text { OR } \\
(95 \% \mathrm{Cl})\end{array}$ & $\begin{array}{c}\text { Model } 5 \\
\text { OR } \\
(95 \% \mathrm{Cl})\end{array}$ \\
\hline \multicolumn{6}{|l|}{ Tingkat asupan energi } \\
\hline Kurang & 7,11 & 7,98 & 8,52 & 7,15 & 9,86 \\
\hline Cukup & $(2,84-17,78)^{\star}$ & $(3,02-21,05)^{*}$ & $(3,27-22,25)^{*}$ & $(2,84-18,01)^{*}$ & $(3,49-27,89)^{*}$ \\
\hline \multicolumn{6}{|l|}{ Tingkat asupan protein } \\
\hline Kurang & 1,24 & 1,22 & 1,24 & 1,22 & 1,18 \\
\hline Cukup & $(0,52-2,96)$ & $(0,50-2,99)$ & $(0,52-2,99)$ & $(0,51-2,95)$ & $(0,47-2,92)$ \\
\hline \multicolumn{6}{|c|}{ Riwayat penyakit infeksi } \\
\hline Ada infeksi & 3,70 & 2,73 & 4,03 & 3,62 & 2,83 \\
\hline Tidak ada infeksi & $(1,53-8,96)^{*}$ & $(1,09-6,86)^{*}$ & $(1,64-9,94)^{*}$ & $(1,48-8,85)^{*}$ & $(1,10-7,31)^{*}$ \\
\hline \multicolumn{6}{|l|}{ Pola asuh } \\
\hline Kurang & 1,39 & 1,39 & 1,34 & 1,26 & 1,21 \\
\hline Baik & $(0,62-3,15)$ & $(0,59-3,21)$ & $(0,58-3,08)$ & $(0,55-2,91)$ & $(0,50-2,92)$ \\
\hline \multicolumn{6}{|l|}{ Berat badan lahir } \\
\hline BBLR & & 5,50 & & & 5,76 \\
\hline Normal & & $(1,48-20,49)^{*}$ & & & $(1,43-23,20)^{*}$ \\
\hline \multicolumn{6}{|l|}{ Pendidikan ayah } \\
\hline Rendah & & & 0,35 & & 2,97 \\
\hline Tinggi & & & $(0,12-1,01)$ & & $(0,93-9,45)$ \\
\hline \multicolumn{6}{|l|}{ Pengetahuan gizi } \\
\hline Kurang & & & & 1,71 & 1,68 \\
\hline Baik & & & & $(0,76-3,81)$ & $(0,72-3,90)$ \\
\hline $\mathrm{R}^{2}(\%)$ & 0,17 & 0,21 & 0,19 & 0,18 & 0,24 \\
\hline $\mathrm{N}$ & 128 & 128 & 128 & 128 & 128 \\
\hline
\end{tabular}

* Signifikan $(p<0,05)$ 
Tabel 5. Analisis stratifikasi variabel berat badan pada hubungan tingkat asupan energi dengan kejadian gizi buruk pada balita

\begin{tabular}{ccccccc}
\hline Variabel & $\begin{array}{c}\text { Tingkat asupan } \\
\text { energi }\end{array}$ & $\begin{array}{c}\text { Gizi buruk } \\
\text { (kasus) }\end{array}$ & $\begin{array}{c}\text { Normal } \\
\text { (kontrol) }\end{array}$ & $\begin{array}{c}\text { OR strata } \\
\text { (95\% Cl) }\end{array}$ & $\begin{array}{c}\text { COR } \\
\text { (95\% Cl) }\end{array}$ & $\begin{array}{c}\text { OR } \\
\text { MH }\end{array}$ \\
\hline Berat badan lahir rendah & Kurang & 12 & 0 & & & \\
& Cukup & 5 & 4 & & 4,89 & 6,17 \\
Berat badan lahir normal & Kurang & 38 & 27 & \multirow{2}{*}{5,16} & & \\
& Cukup & 9 & 33 & & & \\
\hline
\end{tabular}

Tabel 6. Analisis stratifikasi variabel berat badan pada hubungan riwayat penyakit infeksi dengan kejadian gizi buruk pada balita

\begin{tabular}{|c|c|c|c|c|c|c|}
\hline Variabel & $\begin{array}{l}\text { Riwayat penyakit } \\
\text { infeksi }\end{array}$ & $\begin{array}{c}\text { Gizi buruk } \\
\text { (kasus) }\end{array}$ & $\begin{array}{c}\text { Normal } \\
\text { (kontrol) }\end{array}$ & $\begin{array}{l}\text { OR strata } \\
(95 \% \mathrm{Cl})\end{array}$ & $\begin{array}{c}\text { COR } \\
(95 \% \mathrm{Cl})\end{array}$ & $\begin{array}{l}\text { OR } \\
\text { MH }\end{array}$ \\
\hline \multirow[t]{2}{*}{ Berat badan lahir rendah } & Ada infeksi & 15 & 4 & \multirow{2}{*}{$\sim$} & \multirow{4}{*}{2,15} & \multirow{4}{*}{1,61} \\
\hline & Tidak ada infeksi & 2 & 0 & & & \\
\hline \multirow{2}{*}{ Berat badan lahir normal } & Ada infeksi & 26 & 25 & \multirow{2}{*}{1,73} & & \\
\hline & Tidak ada infeksi & 21 & 35 & & & \\
\hline
\end{tabular}

bermakna dengan gizi buruk dan nilai $\mathrm{R}^{2}$ terbesar (24\%).

Berdasarkan analisis stratifikasi Tabel 5, menunjukkan bahwa variabel BBLR merupakan variabel confounding terhadap hubungan tingkat asupan energi dengan kejadian gizi buruk pada balita. Hal ini terlihat dari hasil crude OR dengan OR Mantel-Haenszel memiliki selisih lebih dari $20 \%$ yaitu $26,1 \%$.

Berdasarkan hasil analsis stratifikasi Tabel 6, menunjukkan hasil crude OR dengan OR MantelHaenszel selisihnya lebih dari $20 \%$ yaitu $25,12 \%$, sehingga variabel berat badan merupakan variabel confounding terhadap hubungan riwayat penyakit infeksi dengan kejadian gizi buruk pada balita.

\section{BAHASAN}

\section{Hubungan antara asupan energi dengan gizi buruk}

Hasil analisis bivariat menunjukkan terdapat hubungan signifikan antara tingkat asupan energi dengan kejadian gizi buruk pada balita (Tabel 2). Begitu pula pada analisis multivariat dengan mengikutsertakan variabel BBLR secara bersamasama, dengan pertimbangan bahwa variabel BBLR memiliki $p<0,25$ pada analisis bivariat, menunjukkan nilai OR sebesar 9,86 artinya balita yang memiliki asupan energi yang kurang memiliki risiko 9,86 kali lebih besar menderita gizi buruk dibandingkan dengan balita yang memiliki tingkat asupan energi yang cukup (Tabel 4). Balita yang berat badan lahir normal $(\geq 2.500 \mathrm{~g}$ ) dapat menurunkan risiko gizi buruk sebesar 5,76 kali dibandingkan dengan balita yang memiliki riwayat BBLR (<2.500 g) (Tabel 4). Hal ini sejalan dengan penelitian yang mengemukakan bahwa balita yang memiliki asupan energi kurang berpeluang lebih besar untuk menderita gizi buruk dibandingkan dengan balita yang memiliki asupan energi yang cukup (5). Penelitian yang serupa mengemukakan bahwa terdapat hubungan antara asupan energi dengan status gizi dan asupan energi merupakan faktor risiko terjadinya gizi buruk (6). Hasil penelitian lain juga mengemukakan bahwa total kosumsi energi berhubungan dengan kejadian gizi buruk dan merupakan faktor risiko (7).

Terdapat hubungan antara asupan energi dengan kejadian gizi buruk. Hal ini disebabkan oleh jumlah glukosa dari diet tidak tersedia dan cadangan glikogen juga habis, sehingga sumber energi nonkarbohidrat yaitu lipid dan protein harus digunakan. Lipid dan protein harus diubah menjadi glukosa baru yang selanjutnya mengalami katabolisme untuk menghasilkan energi. Proses ini disebut jalur glukoneogenesis. Lipid dan protein digunakan untuk membentuk energi sehingga tidak dapat melakukan fungsi utamanya akibatnya metabolisme di dalam tubuh terganggu, 
yang mengakibatkan gangguan pertumbuhan. Berdasarkan hal tersebut, Wirjatmadi (8) mempertegas bahwa metabolisme sama dengan orang dewasa tetapi mereka lebih aktif berkembang sehingga membutuhkan asupan zat gizi untuk pertumbuhannya. Semakin muda umur seorang anak, maka lebih banyak asupan makanan yang akan dibutuhkan untuk setiap kilogram berat badannya (8). Gejala yang ditimbulkan apabila anak mengalami kekurangan asupan antara lain: kurang perhatian, gelisah, lemah, cengeng, kurang bersemangat, dan penurunan daya tahan terhadap penyakit infeksi. Kekurangan energi dalam jangka waktu yang lama dapat menyebabkan marasmus pada anak (1).

Hasil analisis stratifikasi diketahui bahwa variabel berat badan merupakan variabel confounding pada hubungan tingkat asupan energi dengan kejadian gizi buruk pada balita. Hal ini terlihat dari selisih OR crude dengan OR Mantel-Haenszel yang lebih dari 20\% (Tabel 5). Hal ini dapat disebabkan oleh balita BBLR memiliki organ-organ tubuh yang belum sempurna, sehingga apabila dipaksa untuk meningkatkan berat badan sama dengan balita normal, akan merusak organorgan tubuhnya.

\section{Hubungan antara asupan protein dengan kejadian gizi buruk}

Berdasarkan hasil analisis bivariat, menunjukkan bahwa tidak ada hubungan signifikan antara asupan protein dengan kejadian gizi buruk $(p>0,05)$ (Tabel 2). Begitu pula pada analisis multivariat dengan mengikutsertakan variabel berat badan secara bersama-sama, menunjukkan nilai OR sebesar 1,18 (Tabel 4). Hasil penelitian ini sejalan dengan penelitian yang mengemukakan bahwa tidak terdapat hubungan antara tingkat konsumsi protein dengan kejadian gizi buruk di Gorontalo dan Makassar $(6,7)$, namun tidak sejalan penelitian di Vietnam dan Pati $(9,10,11)$. Tidak terdapatnya hubungan antara asupan protein dengan kejadian gizi buruk disebabkan oleh ratarata asupan protein pada kelompok kasus (balita gizi buruk) cukup. Akan tetapi, rata-rata asupan energi rendah, sehingga saat tubuh kekurangan energi, fungsi protein untuk menghasilkan energi atau untuk membentuk glukosa akan didahulukan. Bila glukosa atau asam lemak di dalam tubuh terbatas, sel terpaksa menggunakan protein untuk membentuk glukosa dan energi. Oleh karena itu, dibutuhkan konsumsi karbohidrat dan lemak yang cukup tiap hari untuk pembentukan sel-sel tubuh (1). Kekurangan asupan protein dalam jangka waktu yang lama dapat menyebabkan kwashiorkor pada anak-anak di bawah lima tahun. Selain itu, ada faktor lain yang mempengaruhi kejadian gizi buruk di antaranya penyakit infeksi dan BBLR.

\section{Hubungan antara penyakit infeksi dengan kejadian gizi buruk}

Berdasarkan hasil analisis bivariat, diketahui adanya hubungan signifikan antara riwayat penyakit infeksi dengan kejadian gizi buruk pada balita $(p<0,05)$ (Tabel 2). Begitu pula pada analisis multivariat dengan mengikutsertakan variabel berat badan, pendidikan ayah, dan pengetahuan gizi ibu secara bersama-sama, menunjukkan nilai OR sebesar 2,83 artinya balita yang memiliki riwayat penyakit infeksi memiliki risiko 2,83 kali lebih besar menderita gizi buruk dibandingkan dengan balita yang tidak memiliki riwayat penyakit infeksi (Tabel 4). Balita yang berat badan lahir normal dapat menurunkan risiko gizi buruk sebesar 5,76 kali dibandingkan dengan balita yang memiliki riwayat BBLR. Balita yang memiliki ayah dengan pendidikan tinggi dapat menurunkan risiko gizi buruk sebesar 2,97 kali dibandingkan dengan yang ayahnya berpendidikan rendah (Tabel 4). Balita yang memiliki ibu dengan pengetahuan gizi baik dapat menurunkan risiko gizi buruk sebesar 1,68 kali lebih besar dibandingkan dengan yang ibunya berpendidikan rendah. Hal ini sejalan dengan penelitian yang mengemukakan bahwa terdapat hubungan antara status gizi dengan penyakit infeksi $(12,13)$.

Pada penelitian ini, terdapat hubungan yang signifikan antara penyakit infeksi dengan kejadian gizi buruk $(p<0,05)$. Hal ini sesuai dengan penelitian yang mengemukakan bahwa penyakit infeksi merupakan faktor determinan terjadinya gizi buruk. Hal ini disebabkan oleh penyakit infeksi yang berulang atau tidak ditangani dengan segera dapat menyebabkan balita kehilangan nafsu makan, 
malabsorbsi gizi, dan perubahan metabolisme tubuh yang menyebabkan berkurangnya asupan makanan, yang akhirnya akan berdampak pada status gizi balita (kegagalan pertumbuhan) $(14,15)$.

Hasil analisis stratifikasi menunjukkan hubungan riwayat penyakit infeksi dengan kejadian gizi buruk pada balita dengan variabel berat badan yang merupakan variabel confounding (Tabel 6). Hal ini terlihat dari nilai OR crude dan OR MantelHaenzel lebih dari 20\%. Balita BBLR akan lebih rentan terhadap penyakit karena zat anti kekebalan kurang sempurna, sehingga lebih mudah terkena penyakit terutama penyakit infeksi. Penyakit ini menyebabkan balita kurang nafsu makan, sehingga asupan makanan yang masuk ke dalam tubuh menjadi berkurang dan dapat menyebabkan gizi buruk. Di samping itu, balita yang lahir dengan BBLR disebabkan oleh kurangnya asupan gizi ibu serta sering terdapatnya infeksi pada janin selama dalam kandungan. Penyakit infeksi pada ibu yang sedang hamil dapat menyalurkan kumannya ke janin. Selanjutnya infeksi yang terjadi pada janin akan mempengaruhi pertumbuhan bayi ke depannya.

\section{Hubungan antara pola asuh dengan kejadian gizi buruk}

Berdasarkan analisis bivariat, terlihat tidak adanya hubungan antara pola asuh dengan kejadian gizi buruk $(p>0,05)$ (Tabel 2). Begitu pula dengan analisis multivariat dengan mengikutsertakan variabel BBLR, pendidikan ayah, dan pengetahuan gizi ibu secara bersama-sama, menunjukkan nilai OR sebesar 1,21 artinya terdapat kecenderungan bahwa anak yang memiliki pola asuh kurang berisiko menderita gizi buruk lebih besar dibandingkan dengan anak yang memiliki pola asuh yang baik dari orang tuanya (Tabel 4). Sejalan dengan hal tersebut Nurlila mengemukakan bahwa pola asuh yang buruk berisiko mengalami kejadian gizi buruk dibandingkan dengan balita yang memiliki pola asuh yang baik (5). Penelitian ini sejalan dengan penelitian di Desa Mulya Harja (16), namun, bertentangan dengan penelitian di Gorontalo (6).

Tidak terdapatnya hubungan antara pola asuh dengan kejadian gizi buruk dapat disebabkan oleh pola asuh pada kelompok kasus (balita gizi buruk) sudah baik. Hal ini berarti balita yang memiliki pola asuh ibu yang baik memiliki peluang yang sama menderita gizi buruk. Salah satu penyebab gizi buruk pada balita di daerah ini adalah penyakit infeksi. Walaupun pola asuh ibu baik, apabila anak memiliki penyakit infeksi, maka dapat menyebabkan gizi buruk pada anak karena penyakit infeksi merupakan faktor langsung menyebab gizi buruk. Menurut Soetjiningsih (17), pola pengasuhan sangat mempengaruhi pertumbuhan dan perkembangan anak, karena anak yang mendapat perhatian lebih baik secara fisik maupun emosional keadaan gizinya lebih baik dibandingkan dengan teman sebayanya yang kurang mendapat perhatian.

\section{KESIMPULAN DAN SARAN}

Tingkat asupan energi dan riwayat penyakit infeksi merupakan faktor risiko kejadian gizi buruk pada balita di Kecamatan Dampelas, Kabupaten Donggala Provinsi Sulawesi Tengah dengan risiko masing-masing 9,86 dan 2,83.

Tingkat asupan protein dan pola asuh bukan merupakan faktor risiko kejadian gizi buruk pada balita di Kecamatan Dampelas, Kabupaten Donggala Provinsi Sulawesi Tengah. Untuk mengurangi risiko kejadian gizi buruk pada balita di Kecamatan Dampelas dapat dilakukan dengan cara melakukan pendampingan bagi ibu hamil sehingga jumlah BBLR dapat berkurang.

Untuk meningkatkan konsumsi energi dan protein pada balita dilakukan dengan mengoptimalkan pemberikan makanan tambahan (PMT) pemulihan untuk balita yang berisiko gizi buruk dan melakukan monitoring sehingga pemberian PMT tepat sasaran. Selain itu pula, program ini harus lebih meningkatkan pengetahuan ibu dalam hal memilih bahan makanan dengan memperhatikan kualitas serta kuantitasnya.

Untuk meningkatkan pola asuh orang tua dalam hal cara merawat balita terkait pemberian asupan khususnya balita gizi buruk dilakukan dengan penyuluhan berupa demo masak atau cara pembuatan serta pengolahan baik, sehingga orang tua dapat menyediakan asupan yang baik kepada balita dengan kualitas dan kuantitas yang terjamin. 


\section{RUJUKAN}

1. Almatsier S. Prinsip dasar ilmu gizi. Jakarta: Gramedia Pustaka Utama; 2010.

2. Hidayat $Y$, Asrin, Sumarni. Analisis faktor-faktor yang mempengaruhi kejadian gizi buruk pada balita di Kabupaten Kebumen tahun 2010. J Ilmiah Kebidanan. 2011;3(2).

3. Kementerian Kesehatan RI. Riset kesehatan dasar (Riskesdas). Jakarta: Badan Penelitian dan Pengembangan Kesehatan Kementerian Kesehatan RI; 2013.

4. Dinas Kesehatan Kabupaten Donggala. Laporan tahunan program perbaikan gizi masyarakat. Donggala: Dinas Kesehatan Kabupaten Donggala; 2013.

5. Nurlila UR. Faktor penyebab gizi buruk pada anak balita di wilayah kerja Puskesmas Mata Kota Kendari. J STIKES Mandala Waluya Kota Kendari. 2011.

6. Mustapa Y, Sirajuddin S, Salam A. Analisis faktor determinan kejadian masalah gizi pada anak balita di wilayah kerja Puskesmas Tilote Kecamatan Tilango Kabupaten Gotontalo tahun 2013. Jurnal Universitas Hasanuddin Makassar. Makassar; 2013.

7. Susanty M, Kartika M, Hadju V, Alharini S. Hubungan pola pemberian ASI dan MP-ASI dengan gizi buruk pada anak usia 6-24 bulan di Kelurahan Pannampu Makassar. J Media Gizi Masy Indones. 2012;1(2):97-103.

8. Wirjatmadi B, Adriani M. Pengantar gizi masyarakat. Jakarta: Kencana Prenada Media Group; 2012.

9. Le HT, Nga VTT. Malnutrition practice among etchic minorities and child malnutrition in
Mountainous Areas of Central Vietnam. Food Nutr Sci. 2013;4:82-9.

10. Lutviana E, Budiono I. Prevalensi dan determinan kejadian gizi kurang pada balita (studi kasus pada keluarga nelayan di Desa Bajomulyo Kecamatan Juwana, Kabupaten Pati). J Kesehat Masy. 2010;5(2):165-72.

11. Nurcahyo K, Briawan D. Konsumsi pangan, penyakit infeksi dan status gizi anak balita pasca perawatan gizi buruk. J Nutr Food. 2010;5(3):164-70.

12. Kusriadi. Analisis faktor resiko yang mempengaruhi kejadian kurang gizi pada balita di Nusa Tenggara Barat. Institut Pertanian Bogor; 2010.

13. Ryadinency R. Asupan gizi makro, penyakit infeksi dan status pertumbuhan anak di kawasan pembuangan akhir Makassar. J Media Gizi Masy Indones. 2012;2(1):49-53.

14. Ngallaba SE, Daniel J, Makerere, Anthony K, Stella M, Basinda. Outcome and effectiveness of inpatient care of malnourished under five children in District Hospitals of Mwanza Region, North Western Tanzania. J Prev Med. 2014;4:293-8.

15. Ulfani $H$, Martianto D, Baliwati F. Faktor-faktor sosial ekonomi dan kesehatan masyarakat kaitannya dengan masalah gizi underweight, stunted dan wasted di Indonesia pendekatan ekologi gizi. J Nutr Food. 2011;6(1):59-65.

16. Masyithah T. Hubungan pola asuh makan dan kesehatan dengan status gizi anak balita di Desa Mulya Harja. J Media Gizi Kel. 2005;29(2):29_ 39.

17. Soetjiningsih. Tumbuh kembang anak. Jakarta: EGC; 2012. 